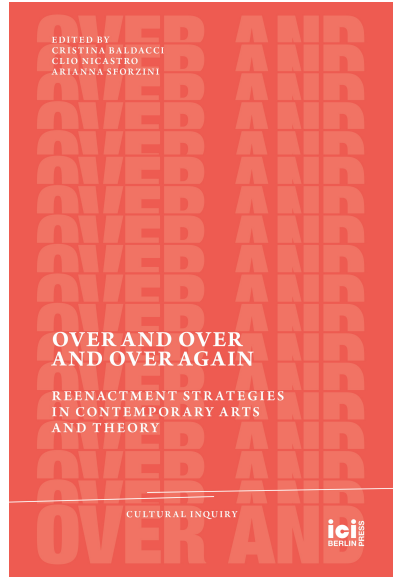

Over and Over and Over Again: Reenactment Strategies in Contemporary Arts and Theory, ed. by Cristina Baldacci, Clio Nicastro, and Arianna Sforzini, Cultural Inquiry, 21 (Berlin: ICI Berlin Press, 2022), pp. 57-67

\section{KATJA GENTRIC}

\section{'Interrupting the Present'}

\section{Political and Artistic Forms of Reenactments in South Africa}

\section{CITE AS:}

\begin{abstract}
Katja Gentric, "Interrupting the Present': Political and Artistic Forms of Reenactments in South Africa', in Over and Over and Over Again: Reenactment Strategies in Contemporary Arts and Theory, ed. by Cristina Baldacci, Clio Nicastro, and Arianna Sforzini, Cultural Inquiry, 21 (Berlin: ICI Berlin Press, 2022), pp. 57-67 <https://doi.org/10.37050/ci-21_07>
\end{abstract}

\section{RIGHTS STATEMENT:}

\author{
(C) by the author(s) \\ Except for images or otherwise noted, this publication is licensed \\ under a Creative Commons Attribution-ShareAlike 4.0 Inter- \\ national License.
}

ABSTRACT: A sense of repetition pervades contemporary South African political and cultural debate. Several recent studies have drawn attention to the fact that the renewed student protests since March 2015 parallel several features of the resistance and liberation movements of the 1970 s and 1980s. At a pivotal position between the two moments of political struggle stands the 'miracle' of the peaceful transition in 1994. Within this set of circumstances a group of curators, artists, and writers, Gabi Ngcobo and Kemang Wa Lehulere, amongst others, formed a collective under the name CHR (Center for Historical Reenactments) in Johannesburg in 2010. The CHR has pursued several questions that interrogate the complexity of a shared memory bridging segregated Apartheid legacy: how do readings of the past inform contemporary urgencies, and what are the political potentials of artistic interpretations of histories? How do they participate in the formation of new subjectivities?

KEYWORDS: Center for Historical Reenactments; Truth and Reconciliation Commission 


\section{'Interrupting the Present' Political and Artistic Forms of Reenactments in South Africa \\ KATJA GENTRIC}

A sense of things repeating themselves, or that of some unfinished business, pervades contemporary South African political and cultural debate. Conflicts arising in South Africa today need to be addressed, while simultaneously keeping in mind the conflicts of the past. This remark systematically comes forward in analyses of the renewed student protests receiving media attention since March 2015; the same observation is also relevant in reference to the crises of what is referred to as 'xenophobic' attacks attaining national proportions in 2008. ${ }^{1}$ Today's student movements parallel several features of the South African resistance and liberation movements, most importantly the 1976 student uprisings. ${ }^{2}$ Likewise, it can be argued that contemporary questions of migration (and the linked xenophobic attacks) have to be viewed in the context of the 1952 Pass Laws Act and the artificially imposed migrant labour system under apartheid, which led to severe conflicts in South Africa as early as $1960 .^{3}$ At a pivotal position between these moments

1 Marietta Kesting, Affective Images: Post-Apartheid Documentary Perspectives (New York: State University of New York Press, 2017), note 21, p. 205.

2 Kylie Thomas, 'Decolonisation Is Now: Photography and Student-Social Movements in South Africa', Visual Studies, 33.1 (2018), pp. 98-110<https://doi.org/10.1080/ 1472586X.2018.1426251>.

3 Kesting, Affective Images. 
of political struggle stands what has been referred to as the 'miracle' of the peaceful transition in 1994, helped along in an almost administrative way by the process of the Truth and Reconciliation Commission (TRC) hearings from 1996 to 2001.

\section{THE TRUTH AND RECONCILIATION COMMISSION AND ITS MEDIATIZATION}

The TRC was intended to be a forum where the wrongs of the past were to be brought into the open, and the nation would henceforth be able to proceed as though a shared memory bridging segregated apartheid legacy had come into existence. ${ }^{4}$ With this goal in mind, much attention was given to media coverage. All hearings were transmitted by radio broadcast; national television dedicated a weekly analytical programme to the TRC, the minutes of the hearings have since been made available on dedicated websites, ${ }^{5}$ and the proceedings have been published in five volumes in $1998 .^{6}$

In his introduction to these proceedings, the chairperson of the commission, Archbishop Desmond Tutu, acquiesces that there would necessarily be controversy regarding the TRC process, but he points out that, in his opinion, the most important legacy of the hearings would be the archives they produced, allowing further research to start taking place. Today, more than twenty years after the last hearings, analyses from a wide spectrum of perspectives have become available. ${ }^{7}$

One incident became a widely recognized representation of the TRC in public imaginaries. It is the demonstration of the 'wet bag

4 Historical Papers (The Library, University of the Witwatersrand) and South African History Archive, Traces of Truth: Documents Relating to the South African Truth and Reconciliation Commission <http://truth.wwl.wits.ac.za/about.php> [accessed 6 April 2018].

5 Truth and Reconciliation Commission, The TRC Report <https://www.justice.gov. za/trc/report/index.htm> and Traces of Truth <http://truth.wwl.wits.ac.za> [accessed 6 April 2018].

6 Truth and Reconciliation Commission, Truth and Reconciliation Commission of South Africa Report, 5 vols (London: Macmillan, 1999). Prior to this international edition, the Report was published in South Africa in October 1998 (Cape Town: Juta, 1998).

7 Historical Papers (The Library, University of the Witwatersrand) and South African History Archive, 'Traces of Truth: Select Bibliography of the South African Truth and Reconciliation Commission (TRC)', Traces of Truth, $2008<$ http://truth.wwl.wits.ac. za/TRCBIB.pdf> [accessed 9 April 2021]. 
method' by a former special branch detective, Jeffrey Benzien. ${ }^{8}$ This rudimentary reenactment was set up spontaneously because the victim had asked to see what had been done to him. ${ }^{9}$ The press photographs taken during the hearing show the former special branch detective crouching over a handcuffed man lying facedown on the floor. A bag is pulled over his head. The TRC proceedings note Benzien's explanation of his torture method, which consisted of the repeated near-suffocation of the interrogated detainee until his testimony was obtained. ${ }^{10}$

While it remains debatable whether the TRC produced the hoped-for benefits within South African society at large, it has inspired several forms of artistic practice and led to more and more astute analyses of photographs produced in this context. ${ }^{11}$ During Documenta 11, curated by Okwui Enwezor, one platform explored commissions set up to investigate human rights violations under military regimes from the early 1980s onward. Rory Bester contributed an analysis of the South African TRC and the polemical contradiction arising when giving an account of intimate and traumatic experiences in an atmosphere of spectacle within the staged circumstances of a public hearing: 'In the space between memory and amnesia, between the trauma of memory and the comfort of forgetting, how do we re-present the TRC without turning it into a spectacle?'12

\section{THE CENTER FOR HISTORICAL REENACTMENTS,} JOHANNESBURG

Within this set of circumstances, a group of curators, artists, and writers - Gabi Ngcobo, Kemang Wa Lehulere, and Donna Kukama

8 'Twenty Years of Democracy, Truth and Reconciliation Commission', image by George Hallet <http://www.specialcollections.uct.ac.za/20-years/truthreconciliation-commission $>$ [accessed 22 November 2020].

9 Rory Bester, 'Trauma and Truth', in Experiments with Truth: Transitional Justice and the Processes of Truth and Reconciliation: Documenta 11_Platform 2, ed. by Okwui Enwezor (Ostfildern: Hatje Cantz, 2002), pp. 155-73 (p. 167).

10 The Truth and Reconciliation Commission, Truth and Reconciliation Commission of South Africa Report, II, pp. 188-90.

11 Kylie Thomas, 'Exhuming Apartheid: Photography, Disappearance and Return', Cahiers d'études africaines, 230 (2018), pp. 429-54.

12 Bester, 'Trauma and Truth', p. 173. 
amongst others - formed a collective named Center for Historical Reenactments (CHR) in 2010. Two of the key actions performed by artists later to become CHR members happened before this date.

The first of these, planned as a three-day intervention, was performed in a backyard in Gugulethu in 2008. Accompanied by a sound recording of the artist combing his hair, Kemang Wa Lehulere dug a hole in the ground using an afro-comb as a digging tool. Titled $u$ Guqul'ibhatyi ('to turn a coat inside out', an expression linked to race reclassification under apartheid), the action was meant to be a gesture of unearthing erased personal stories and traumatic questions of identity. At about one meter in depth the digger hit upon bones, which turned out to be part of a rib cage. The incident and the unravelling of the uncanny situation following the discovery are retold in an interview with Gabi Ngcobo. ${ }^{13}$ Wa Lehulere has since performed a number of such digging actions, never knowing what 'historical rubble' he might unearth.

The second is an action by Donna Kukama, performed in 2009 on the site of Kwa-Mai-Mai, a traditional healer's market in central Johannesburg. The Swing (after after Fragonard) ${ }^{14}$ is hung under the gigantic concrete structure of the highway bypass bridging the market. The artist, daintily dressed in white, swings several meters above the shoppers, throwing bank notes into the crowd and provoking a commotion. In mid-action the wooden seat of the swing accidentally snapped, and the artist fell several meters to the ground, breaking her right leg. In later projects the CHR revisits this scene and the socioeconomic underpinnings of this action. ${ }^{15}$

13 Gabi Ngcobo and Kemang Wa Lehulere, 'Unearthing Skeletons in History's Shallow Graves', in PASS-AGES, References \& Footnotes, ed. by the Center for Historical Reenactments and the Johannesburg Workshop for Theory and Criticism (Johannesburg: Center for Historical Reenactments, 2010), p. 10.

14 The performance referenced two earlier artistic uses of a swing: Jean-Honoré Fragonard, The Swing, 1767, oil on canvas, $81 \times 64.2 \mathrm{~cm}$, The Wallace Collection, London, and Yinka Shonibare, The Swing (After Fragonard), 2001, installation, 330 x 350 x $220 \mathrm{~cm}$, Tate Modern, London.

15 After-after Tears: Wie sien ons? (2013, video commissioned by the New Museum, New York). Kukama's action was not only a comment on the neo-liberal South African society of today but also a protest to a recent aggression against a female commuter, who had been a victim of 'corrective' methods used by the taxi drivers at Noord Taxi Rank. 


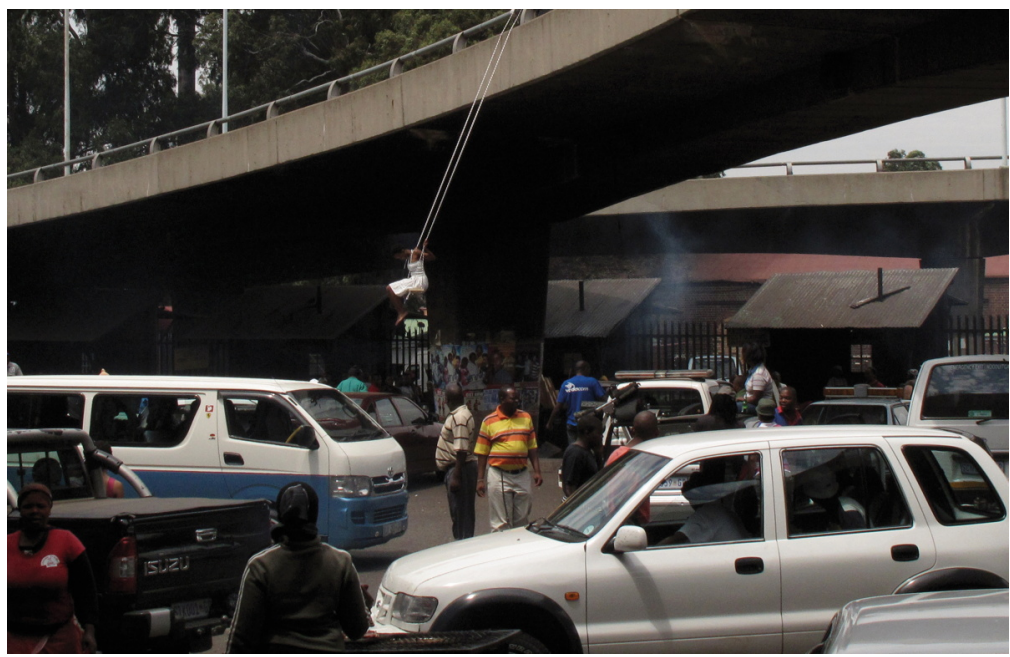

Figure1. Donna Kukama, The Swing (after after Fragonard) (2009), performance and video, 4:54 mins, Photos courtesy: Matthew Burbidge and the artist.

The uncanny link between these two precursory interventions is the coincidence that the actions, both referencing events of the past, were each 'interrupted' by unforeseen circumstances. The interruptive element became the reason for these actions to be revisited again and again by the CHR.

Apart from Kukama's Swing, CHR actions do not resemble understandings of reenactment in other contexts ${ }^{16}$ - very few of the interventions are staged in any way. Instead, the collective may publish newspapers, referring to the past in visual quotations. The members

16 Here, I would like to briefly mention two texts teasing out differences between popular and artistic forms of reenactment and their relationships with history. Both authors think of the final product of a reenactment as a film. Caillet speaks of a revision of an aspect of the past in the present and for the present, with the intent of questioning official history, while simultaneously pointing at compulsive behaviour in certain repetitions (p. 72). Leeb's interest lies not only in the utopic quality of politically motivated reenactments but also in a form of concretized sense of the possible (Möglichkeitssinn), which extends both to the future and to the past but unfolds in the present (pp. 36, 39, 42, 43). Susanne Leeb, 'Flucht nach nicht ganz vorn, Geschichte in der Kunst der Gegenwart', Texte zur Kunst, 76 (December 2009), pp. 28-45. Aline Caillet, 'Le Re-enactment: Refaire, rejouer ou répéter l'histoire?', Marges. Revue d'art contemporain, 17 (2013), special issue Remake, reprise, répétition, pp. 66-73 <https: //doi.org/10.4000/marges.153>. 
of the collective may invest in sites, search through archives, repeat quotes, host communal meals, play word games, or propose repetitive public readings of texts. They may conduct seminars, exhibitions, residencies, and community work, and engage in transversal research processes, subversion and mediation, or counterarchival responses. In short, they seem to avoid acting in any theatrical sense; rather, they enact, putting concepts into praxis.

A routine of carrying out the same gestures time and again, thereby providing the circumstances for difference to set in, ${ }^{17}$ became the modus operandi of the CHR. In this spirit, the CHR established itself in a cyclical appropriation of space in different historically laden sites - for example, $\mathrm{N}^{\circ} 80$ Albert Street in the basement of the former Pass Office, the site that controlled a central aspect of the South African apartheid system: the policing of freedom of 'migration' under the segregated pass laws. ${ }^{18}$ However:

The documents that may have served as testimony to the site's activities have been destroyed, this denied their roles as witnesses and spared the interrogation of the Truth and Reconciliation Commission. Ironically, it is this very emptiness that creates a space for us to call upon our abilities to remember and inject memory (unreliable and slippery as it may be) to the site. ${ }^{19}$

A few months later, the CHR invested in a workspace in another significant location, August House, at the heart of Doornfontein in central Johannesburg. A photograph of the western window and the view from this third-floor vantage point was one of the first posted on the CHR Facebook page. This same window makes a reappearance in sev-

17 Thierry Davila, 'Endurance de la répétition, surgissement de l'invention: Le Remake et la fabrique de l'histoire', in Remakes (Bordeaux: CAPC-Musée d'art contemporain, 2003), pp. 26-46 (pp. 41-42). Davila speaks of repetition in order to observe the differences induced by mnemonic activity - creativity becoming evident in these differences).

18 The building at 80 Albert Street formerly housed Johannesburg's Pass office. After 1994 the building was re-used and housed social projects of a different nature. Khwezi Gule commences his essay about PASS-AGES by evidencing the layers of history this building stands for. Khwezi Gule, 'Center for Historical Reenactments: Is the Tale Chasing its Own Tail?' Afterall: A Journal of Art, Context and Enquiry, 39 (2015), pp. $88-100$.

19 PASS-AGES: References \& Footnotes, p. 2. 
eral later installations. ${ }^{20}$ Ngcobo draws a web of interrelated thoughts through the gesture of 'looking out' of the confined art space. ${ }^{21}$ The window indeed looks out onto the neighbouring streets, with their international bus terminals and 'occupied' buildings, a polyglot social tissue formed by inhabitants coming from all parts of the world. Metaphorically, the CHR addresses this question in an experiment entitled 'Xenoglossia' (the condition where a subject, for an unexplained reason, can speak or write in a language with which he has had no contact). For lack of other evidence, this condition is connected to the possibility of reincarnation. By preferring the (paranormal) state of Xenoglossia to the notion of translation, the CHR chose to address questions of language difference without imposing the foreclosure that equivalence of meaning has to be the only possible outcome of speech acts. One telling experiment with reflexive and partly abstruse forms of language-use was the performance 'Does a mirror have a memory?' The participants engaged in conversation while looking at each other via the mediation of a mirror. Taking its cue from the technical detail that every rear-view mirror has a blind spot, ${ }^{22}$ this exercise was referred to as a 'setup for failed communication'. During the two-year course of the Xenoglossia project, the CHR has performed many such experiments and invited the public to partake in them. ${ }^{23}$

Another way of exploring 'how language has played a central role in some of the greatest historical misunderstandings that have been reincarnated in recent history ${ }^{24}$ is the visual/lexical quotation. In 2012, the CHR proposed reusing a protest banner, famous because of a photograph taken by Alfred Kumalo in Uitenhage in 1985, during a demonstration marking the twenty-fifth anniversary of the Sharpeville Massacre. The banner read: 'They will never kill us all.' The 1985 demonstration gave rise to new excesses on the part of the police, dur-

20 Recreated at the Lyon Biennale of Contemporary Art in 2011 and at New Museum of New York from 22 May to 7 July 2013.

21 Gabi Ngcobo, 'Does This Window Have a Memory?', Other Possible Worlds <http: //www.otherpossibleworlds.net/?page_id=453> [accessed 6 April 2018].

22 Conversation with Donna Kukama, Johannesburg, 27 March 2017.

23 Mbali Khoza, 'What Difference Does It Make Who Is Speaking?' (unpublished master's thesis in Fine Art, University of the Witwatersrand, Faculty of Humanities, School of Art, 2016).

24 Ngcobo, 'Does This Window Have a Memory?'. 
ing which twenty-five people lost their lives. To evoke the massacre of 21 March 1960, the members of the CHR reproduced, in March 2012, the banner of 21 March $1985 .{ }^{25} \mathrm{Ngcobo}$ refers to the works coming out of the engagement with the Alf Kumalo Archive as a way of 'interrupting the present. ${ }^{26}$ These interventions fissure the chronological order of events; they are a 'time-machine, [...] conceiving time as a tool, and setting it out of joint. ${ }^{27} \mathrm{Ngcobo}$ not only thinks of the eerie foreboding wisdom carried by the banner of 1985 , foretelling destiny, but also of a second futuristic work, titled What happened Jo'burg $20^{*} 81$. Here, the CHR speculates about a reversal of time, imagining a world where Nelson Mandela, instead of aging towards his death, would begin to get younger every year - the CHR imagines Mandela in 2081 as a twenty-five-year-old ${ }^{28}$.

On 12 December 2012, in a twelve-hour event, the CHR entered another phase of their cyclical project by staging their own suicide: 'We Are Absolutely Ending This'. Their death marked a conclusion only to open up the possibility of staging their own afterlife, a second coming, in the exhibition 'After-after Tears'. Just as the CHR had started before its inception, it reached far beyond its suicide. Ngcobo, nominated as curator of the 2018 Berlin Biennale, uses phrases generated as part of the Xenoglossia research as titles of sub-sections of the Biennale; Kukama works in series of reiterations as chapters in a book; and Wa Lehulere engages with the work of fellow South African artists silenced under apartheid. ${ }^{29}$ However, what Khwezi Gule interrogates as 'various acts of mutual cannibalism' between 'writing, art-making, historicising, teaching, archiving and curating', still begs the same question: 'How, then, to mobilize history in such a way that it becomes a truly transformative exercise?'30

25 Rise and Fall of Apartheid: Photography and the Bureaucracy of Everyday Life, ed. by Rory Bester and Okwui Enwezor (Munich: Prestel, 2013), pp. 528-29.

26 Gabi Ngcobo, 'Phantom(pain)', Glossary of Common Knowledge, May 2014 <https: //www.youtube.com/watch?v=zqgLd_BdNmI> [accessed 6 April 2018].

27 Ngcobo, 'Phantom(pain)', [00:09:40] and [00:10:52].

28 A performance video was made during the project, which is mentioned on the CHR Facebook page on 20 Mai 2012 and by Gabi Ngcobo (in the text referenced in Note 41 of my text).

29 Kemang Wa Lehulere, Bird Song, ed. by Deutsche Bank AG, Art, Culture \& Sports, Thorsten Strauß and Franziska Kunz (Berlin: Hatje Cantz, 2017).

30 Gule, 'Center for Historical Reenactments', pp. 91 and 99. 


\section{INTERRUPTING THE IM-MEDIATE PRESENT}

A strikingly similar quest for true transformation is expressed by Frantz Fanon. In Fanon's case, this effort is paired with the struggle to overcome the inhibition inflicted by ressentiment in order to become actionnel, i.e., an individual taking action. ${ }^{31}$ Fanon pursues his quest with both remedial care and revolutionary zeal. ${ }^{32}$ A text by Ngcobo reiterates essential aspects of Fanon's thought, presenting it in parallel with the description of an enactment found in a text by Bessie Head: that of a person hiding. In a comic inversion of the process of hide-andseek, the poses of hiding and/or seeking become confused. Ngcobo concludes, 'It is not that difficult for one to settle back into a position one tries to escape or reject ${ }^{33}$ - meaning, after Fanon, that in his quest of recognition and true change, the seeker must remain vigilant not to lose sight of his resolution to act.

The immediate urgencies arising during the recent student protests, with their very strong references to historical misunderstandings, are conducted under the sign of a Fanonian approach to the post-colonial situation. The phrase, 'immediate urgencies', carries two meanings in this context: instantaneous (not removed in time), and im-mediate (not yet mediated) — implying a sense of 'woke'-ness ${ }^{34}$ in the process of becoming articulate. How can these urgencies be (self-) conducted into subjectivation - meaning the possibility of individual responsibility embedded in collective responsibility - a state of being which Achille Mbembe elaborates into a description of an 'ethics of becoming in reciprocal recognition'? ${ }^{35}$ How does the storytelling taken on by the TRC restore individual dignity lost though historical misunderstanding?

31 Frantz Fanon, Peau noire, masques blancs, in Fanon, OEuvres (Paris: La Découverte, 2011), pp. 45-257 (p. 243).

32 Achille Mbembe, Politiques de l'inimitié (Paris: La Découverte, 2016) analyses Fanon's psychoanalytical and political thought and praxis as a pharmakon, that is, as both medicine and poison, thereby considering the possibility of creative violence. See $\mathrm{p}$. 8, p. 10 and also pp. 91-140.

33 Gabi Ngcobo, 'Endnotes. Was It a Question of Power?', in Condition Report: Symposium on Building Art Institutions in Africa, ed. by Koyo Kouoh (Ostfildern: Hatje Cantz, 2013), pp. 65-67, also available at <http://historicalreenactments.org/documents/ condition\%20report/condition.pdf> [accessed 31 March 2019].

34 Thomas, 'Decolonisation Is Now', pp. 98-110.

35 Throughout Politiques de l'inimitié, Mbembe seems to describe what in later publications he will call 'l'éthique du devenir-avec-les-autres'. 
Simultaneously mentioning the 'interruptions into the present' at the Alf Kumalo Archive, Ngcobo quotes Walter Benjamin, who, in his essay 'Excavation and Memory' stated:

He $[s i c]$ who seeks to approach his own buried past must conduct himself like a man digging. Above all, he must not be afraid to return again and again to the same matter; to scatter it as one scatters earth, to turn it over as one turns over soil. For the "matter itself" is no more than the strata which yield their long-sought secrets only to the most meticulous investigation. That is to say, they yield those images that, severed from all earlier associations, reside as treasures in the sober room of our later insights. ${ }^{36}$

While reading what is translated here as 'matter itself', let us bear in mind that the word 'Sachverhalt' used by Benjamin in German communicates an awareness of 'how things exist in their relation to each other'. When Benjamin's text is read from within the art context, the final yield when digging would be an image ('Bild') gleaned from strata of yet unmediated 'historical rubble. This image will represent these events in the collective imagination of the future. ${ }^{37}$ These elementary mnemonic units can be carried either by a figurative image or by words, spoken or written. They are 'Denkbilder', as Benjamin liked to say: thoughts arising out of an image, visual or semantic, holding their own as concepts. Benjamin explains this process of coming-into-image by evoking the action of digging and scattering the dug-up contents around. In South Africa, digging can conjure up quite far-reaching associations; we might think of digging to find the remains of disappeared activists or other actively disremembered details of apartheid

36 Ngcobo quotes this translation in her text for $\operatorname{Fr}$ (agile), a 2012 social sculpture and intervention at the Alf Kumalo Museum in Diepkloof, Soweto <http:// historicalreenactments.org/blog_fragile.html> [accessed 6 April 2018]. For the German original see: Walter Benjamin, 'Ausgraben und Erinnern', in Benjamin, Gesammelte Schriften, ed. by Rolf Tiedemann and Hermann Schweppenhäuser, 7 vols (Frankfurt a. M.: Suhrkamp, 1972-91), IV.1: Kleine Prosa, Baudelaire-Übertragungen (1972), pp. 400-01.

37 Jean-Philippe Antoine, Farces et Attrapes. Inventer les images (Genève: MAMCO; Dijon: Les presses du réel, 2017). Antoine remarks (p. 12): 'Les conditions d'établissement de ce faire image concernent aussi bien des manières de faire de l'histoire que des manières de faire de l'art.' Even more to the point for the context of reenactments, a chapter is titled (pp. 117-37): 'La Reprise: farce, occasion, extraction du nom d'art'. 
past. ${ }^{38}$ In a later text, ${ }^{39}$ following the trail of a film by Michelle Monareng, Ngcobo will put into praxis the migration of imaginative content described by Benjamin. Ngcobo's text leads its readers from a contemporary historical moment (Mandela's burial) to a trip taken with friends today, a journey to a private home. It is a tale told through rumour and legend, a tale of forced removals and of unmarked graves, of objects that imbue people with special powers, of a bull appearing out of the mist to watch a man digging in ancestral soil. Be they speech-acts or reenactments, each of these elements participates in its own way in the common act of carrying on the migration of Ngcobo's '(Denk)bild'. In the context of the CHR, it is possible to claim that the migration of imaginative (i.e., image-making) 'Sachverhalte' can also show itself in the form of a xenoglossic leap, ${ }^{40}$ by which the past or the future comes to disrupt the present, as a protester would, in order to undermine the usual.

Whether looking out of a window on the third floor of a building in polyglot-central Johannesburg, swinging in a back-and-forth motion high above a greedy crowd, digging in a backyard in Gugulethu, or standing on ancestral land with a bull as a solitary onlooker, the CHR is poised as a point of convergence. This point, ephemeral, transient, trans-cient or farsighted, and at the same time retro-futuristic, is a site where images are salvaged out of layers of forgottenness or disremembrance. The main questions explored by the CHR have lost none of their pertinence: how do readings of the past inform contemporary urgencies, and what are the political potentials of artistic interpretations of histories? How do they participate in the 'formation of new subjectivities' ${ }^{41}$

38 On the importance of exhumations during the TRC process, see Kylie Thomas's 'Exhuming Apartheid'.

39 Gabi Ngcobo, 'Art in Context Africa, Part I: Sabelo Mlangeni's No Problem, and a Visit to the Site of Michelle Monareng's Removal to Radium', Art Review, 66.7 (October 2014) <https://artreview.com/features/october_2014_feature_art_ in_context_i_gabi_ngcobo/> [accessed 6 April 2018].

40 The choice of the word 'leap' in this context should recall Fanon (Peau noire, masques blancs, p. 250): 'Je dois rappeler à tout instant que le véritable saut consiste à introduire l'invention dans l'existence.'

41 Cf. <http://historicalreenactments.org/index3.html> [accessed 6 April 2018]. 
Katja Gentric, “Interrupting the Present': Political and Artistic Forms of Reenactments in South Africa', in Over and Over and Over Again: Reenactment Strategies in Contemporary Arts and Theory, ed. by Cristina Baldacci, Clio Nicastro, and Arianna Sforzini, Cultural Inquiry, 21 (Berlin: ICI Berlin Press, 2022), pp. 57-67 <https://doi.org/10.37050/ci-21_07>

\section{REFERENCES}

Antoine, Jean-Philippe, Farces et Attrapes. Inventer les images (Genève: MAMCO; Dijon: Les presses du réel, 2017)

Benjamin, Walter, 'Ausgraben und Erinnern', in Benjamin, Gesammelte Schriften, ed. by Rolf Tiedemann and Hermann Schweppenhäuser, 7 vols (Frankfurt a.M.: Suhrkamp, 197291), Iv.1: Kleine Prosa, Baudelaire-Übertragungen (1972), pp. 400-01

Bester, Rory, 'Trauma and Truth', in Experiments with Truth: Transitional Justice and the Processes of Truth and Reconciliation: Documenta 11_Platform 2, ed. by Okwui Enwezor (Ostfildern: Hatje Cantz, 2002), pp. 155-73

Bester, Rory, and Okwui Enwezor, eds, Rise and Fall of Apartheid: Photography and the Bureaucracy of Everyday Life (Munich: Prestel, 2013)

Caillet, Aline, 'Le Re-enactment: Refaire, rejouer ou répéter l'histoire?', Marges. Revue d'art contemporain, 17 (2013), special issue Remake, reprise, répétition, pp. 66-73 <https://doi. org/10.4000/marges.153>

Center for Historical Reenactments and the Johannesburg Workshop for Theory and Criticism, eds, PASS-AGES, References \& Footnotes (Johannesburg: Center for Historical Reenactments, 2010)

Davila, Thierry, 'Endurance de la répétition, surgissement de l'invention: Le Remake et la fabrique de l'histoire', in Remakes (Bordeaux: CAPC-Musée d'art contemporain, 2003), pp. 26-46

Deutsche Bank AG, Art, Culture \& Sports, Thorsten Strauß, and Franziska Kunz, eds, Kemang Wa Lehulere, Bird Song (Berlin: Hatje Cantz, 2017)

Fanon, Frantz, Peau noire, masques blancs, in Fanon, Euvres (Paris: La Découverte, 2011), pp. 45-257 <https://doi.org/10.1522/030294726>

Gule, Khwezi, 'Center for Historical Reenactments: Is the Tale Chasing its Own Tail?', Afterall: A Journal of Art, Context and Enquiry, 39 (2015), pp. 88-100 <https://doi.org/10.1086/ 682839>

Historical Papers (The Library, University of the Witwatersrand) and South African History Archive, Traces of Truth: Documents Relating to the South African Truth and Reconciliation Commission <http://truth.wwl.wits.ac.za/about.php> [accessed 6 April 2018]

'Traces of Truth: Select Bibliography of the South African Truth and Reconciliation Commission (TRC)', Traces of Truth, 2006 <http://truth.wwl.wits.ac.za/TRCBIB.pdf> [accessed 9 April 2021]

Kesting, Marietta, Affective Images: Post-Apartheid Documentary Perspectives (New York: State University of New York Press, 2017) 
Khoza, Mbali, 'What Difference Does It Make Who Is Speaking?' (unpublished master's thesis in Fine Art, University of the Witwatersrand, Faculty of Humanities, School of Art, 2016)

Leeb, Susanne, 'Flucht nach nicht ganz vorn, Geschichte in der Kunst der Gegenwart', Texte zur Kunst, 76 (December 2009), pp. 28-45

Mbembe, Achille, Politiques de l'inimitié (Paris: La Découverte, 2016)

Ngcobo, Gabi, 'Art in Context Africa, Part I: Sabelo Mlangeni's No Problem, and a Visit to the Site of Michelle Monareng's Removal to Radium', Art Review, 66.7 (October 2014) <https: //artreview.com/features/october_2014_feature_art_in_context_i_gabi_ngcobo/> [accessed 6 April 2018]

—Does This Window Have a Memory?', Other Possible Worlds <http://www. otherpossibleworlds.net/?page_id=453> [accessed 6 April 2018]

_ 'Endnotes. Was It a Question of Power?', in Condition Report: Symposium on Building Art Institutions in Africa, ed. by Koyo Kouoh (Ostfildern: Hatje Cantz, 2013), pp. 65-67 <http://historicalreenactments.org/documents/condition\%20report/condition.pdf> [accessed 31 March 2019]

_ 'Phantom(pain)', Glossary of Common Knowledge, May 2014 <https://www.youtube. com/watch?v=zqgLd_BdNmI> [accessed 6 April 2018]

Ngcobo, Gabi, and Kemang Wa Lehulere, 'Unearthing Skeletons in History's Shallow Graves', in PASS-AGES, References \& Footnotes, ed. by the Center for Historical Reenactments and the Johannesburg Workshop for Theory and Criticism (Johannesburg: Center for Historical Reenactments, 2010), p. 10

Thomas, Kylie, 'Decolonisation Is Now: Photography and Student-Social Movements in South Africa', Visual Studies, 33.1 (2018), pp. 98-110 <https://doi.org/10.1080/1472586X. 2018.1426251>

_ 'Exhuming Apartheid: Photography, Disappearance and Return', Cahiers d'études africaines, 230 (2018), pp. 429-54 <https://doi.org/10.4000/etudesafricaines.22209>

Truth and Reconciliation Commission, The TRC Report <https://www.justice.gov.za/trc/ report/index.htm> [accessed 6 April 2018]

Truth and Reconciliation Commission of South Africa Report, 5 vols (London: Macmillan, 1999) 